\title{
KEMAMPUAN KOMUNIKASI ANAK AUTISME SETELAH PEMBERIAN MAINAN SQUISY
}

\section{Communication Skill of Children With Autism After Given Squishy Toys}

\section{Astri Widiart ${ }^{1 *}$ \\ Angelina Novia \\ Toemon ${ }^{2}$ \\ Dian Mutiasari ${ }^{3}$ \\ Dedy Baboe ${ }^{4}$}

1,3Dapertemen Kesehatan

Masyarakat, Fakultas

Kedokteran, Universitas

Palangka Raya, Kalimantan

Tengah, Indonesia

2Dapertemen Imunologi,

Fakultas Kedokteran,

Universitas Palangka Raya,

Kalimantan Tengah, Indonesia

*email:

rumentaliasulistini@gmail.com

Kata Kunci:

Squishy

Autisme

Komunikasi

\section{Keywords:}

Stroke

Strength

Hand grip

\begin{abstract}
Abstrak
Pendahuluan : Secara umum interaksi sosial anak autis berhubungan erat dengan bagaimana cara komunikasi anak yang memiliki kelainan tersebut. Kegagalan dalam membangun interaksi sosial melalui komunikasi, anak dengan autisme tidak dapat melakukan kontak mata dengan lawan bicaranya, anak lebih senang menyendiri, oleh karena itu sangat diperlukan untuk meminimalisir kesulitan, hambatan/kelemahannya sehingga anak autis dapat melakukan interaksi sosial sesuai dengan tugas perkembangannya. Squishy merupakan sesuatu yang berpori pori menyerupai spons, bertekstur lembut dan kenyal, dan mempunyai kemampuan untuk kembali kebentuk semula. Salah satu penulis di The New York bernama Annaliese Griffin anak usia dini menyebutkan bahwa squishy bisa menjadi sarana untuk melatih gerak sensoris dan lewat teksturnya yang lembut, squishy dapat melatih indera peraba anak. Anak dengan autis dapat berkomunikasi sendiri dan menciptakan teman bayangannya atau mengajak orang tua untuk ikut bermain peran bersama, dapat juga menjadi ajang sosialisasi anak karena ia bermain dengan teman-temannya.
\end{abstract}

Tujuan penelitian : mengetahui pengaruh perkembangan kemampuan anak autisme dalam berkomunikasi pasca pemberian permainan Squishy.

Metode : Desain penelitian yang digunakan dalam penelitian ini adalah quasi experimen yang bertujuan untuk mengidentifikasi pengaruh terapi bermain squishy terhadap peningkatan perkembangan komunikasi pada anak autis dengan pendekatan one group pre post test design yaitu menggunakan satu kelompok subjek peneliti dengan observasi sebelum dan sesudah perlakuan.

Hasil : Pemberian permainan Squisy memberikan dampak yang positif bagi perkembangan komunikasi yang baik bagi penderita anak Autis. Hal ini karena didasari dari hasil penelitian ini sebelum dan sesudah diberikan perlakuan permainan Squisy memiliki hubungan yang bermakna

\begin{abstract}
Introduction: In general, the social interactions of children with autism are closely related to how the children with the disorder communicate. Failure to developing social interaction, makes children with autism unable to make eye contact with their interlocutors, tend to isolate themselves from social interaction, , therefore it is very necessary to minimize difficulties, obstacles/weaknesses so that children with autism can carry out social interactions. Squishy is a toy that has pores like a sponge, has soft texture, dan elastic, it also has ability to return to original form. Annaliese Griffin, The New York writer claimed that Squishy could be used as a medium to developing motor skills and throught Squishy's soft texture, it also could be used to developing children sense of touch. Children with autism can communicate with themself, creating an imaginary friend, or inviting their parents to participate doing role playing together, it also could be a place to children carry out social interraction because they play with their friends.
\end{abstract}

Purposes of The Study: to understand communication skill of children with autism development after given them Squishy Toys

Study Methods: The research design used in this study is a quasi experimental study which aims to identify the effect of playing squishy therapy on improving communication development in autistic children with a one group pre-post test design approach, namely using one group of research subjects with pre- and post-treatment observations.

Result: Giving Squisy Toys has a positive impact on the development of communication skill for children with autism. This is because based on the previous study and after being given the Squisy toys treatment, it has a significant relationship. 


\section{PENDAHULUAN}

Diperkirakan penderita autis di dunia sebanyak 21,7 juta. UNESCO sebagai Badan Dunia untuk Pendidikan dan Kebudayaan, pada 20 II lalu memperkirakan bahwa ada 35 juta orang dengan autisme di dunia yang disiarkan melalui CNN pada 7 April 2016 lalu. Pada liputan tersebut rata-rata ada 6 orang per 1000 orang dengan autis dari populasi dunia. Data 2014 diAmerika Serikat ada sebesar I,5 persen atau I dari 68 anak mengalami autistik, meningkat 30 persen dari 20I2, yang memiliki perbandingan I banding 88 anak. Di Indonesia sendiri belum ada data resmi yang menyatakan jumlah pasti anak dengan kondisi autisme, tapi riset di beberapa tempat di dunia sempat menyatakan telah terjadi peningkatan pengidap autis.'

Secara etimologis kata autisme berasal dari kata auto dan isme, auto artinya diri sendiri, sedangkan isme berarti suatu aliran atau paham. Autisme bisa diartikan sebagai suatu paham yang hanya tertarik pada dunianya sendiri. $^{2}$ Autis merupakan gangguan proses perkembangan yang terjadi dalam tiga tahun pertama yang menyebabkan gangguan pada bahasa, kognitif, sosial dan fungsi adaptif, sehingga anak-anak tersebut semakin lama tertinggal perkembangannya dibandingkan teman-teman seusia mereka. ${ }^{3}$ Anak autis tentunya akan mengalami perbedaan komunikasi dalam berinteraksi sosial dengan anak normal karena anak autis memiliki tiga gangguan pokok dalam komunikasi, interaksi sosial dan perilaku. Anak autis cenderung sibuk sendiri sehingga gangguan-gangguan yang dialami anak autis kadang tidak dimengerti oleh orang-orang di sekitanya. ${ }^{4}$ Garfin dan Lord menyebutkan bahwa kompetensi berkomunikasi merupakan faktor utama yang menentukan seberapa besar orang dengan autisme dapat mengembangkan hubungan dengan orang lain dan berpartisipasi dalam kegiatan sehari-hari. ${ }^{5}$ Autisme pada masing-masing anak juga dapat berbeda tingkat atau derajat keberatan gejalanya (level of severity). Anak dengan autisme berat akan mengalami kesulitan mengembangkan bahkan pada kemampuan komunikasi pendahuluan, contohnya: anak dengan autisme sulit membuat kontak mata dengan orang untuk mengajak kontak sosial. Sedangkan anak dengan gejala ringan, kemungkinan besar hal yang sulit dilakukannya adalah spontanitas penggunaan komunikasi reseptif dan komunikasi ekspresif, serta tantangan penggunaan komunikasi pragmatis agar mereka lebih mampu menyampaikan informasi pada orang-orang di sekitarnya. Hambatan komunikasi membuat anak dengan autisme mengalami kesulitan dalam belajar dari mengamati orang lain di sekitarnya. ${ }^{6}$

Squishy berasal dari bahasa Inggris yang bisa diartikan sebagai sesuatu yang berpori pori menyerupai spons, bertekstur lembut dan kenyal, dan mempunyai kemampuan untuk kembali kebentuk semula. Dibalik bentuk dan aromanya, squishy ternyata memiliki banyak manfaat buat anak. Salah satu penulis The New York Times (Annaliese Griffin) menyebut squishy digunakan untuk meredakan stres dan kegelisahan. Squishy memiliki kegunaan seperti membuat anak tetap tenang yang disebabkan karena ada stimulasi pada saraf-saraf di tangan yang terhubung langsung dengan otak. Kegunaan lain yang sangat berpengaruh yaitu dapat meningkatkan kreatvitas dan kemampuan sosial anak. Dari berbagai squishy yang dimiliki, anak bisa meningkatkan kreativitasnya dengan berkomunikasi sendiri dan menciptakan teman bayangannya atau mengajak orang tua untuk ikut bermain peran bersama, dapat juga menjadi ajang sosialisasi anak karena ia bermain dengan teman-temannya.

Maka dari itu perlu tindakan lebihlanjut untuk diteliti seberapa berpengaruhkah efek permainan Squshy terhadap peningkatan komunikasi bagi anak-anak yang mengalami autisme.

\section{METODOLOGI}

Desain penelitian yang digunakan dalam penelitian ini adalah quasi experimen yang bertujuan untuk mengidentifikasi pengaruh terapi bermain squishy 
terhadap peningkatan perkembangan komunikasi pada anak autis dengan pendekatan one group pre post test design yaitu menggunakan satu kelompok subjek peneliti dengan observasi sebelum dan sesudah perlakuan.

Populasi dalam penelitian ini adalah anak penderita autis yang rutin melakukan kunjungan di Rumah Autis Kota Palangka Raya, dengan toal sampel 3 I orang.

Terapi bermain squisy dalam penelitian ini adalah menggunakan squishy dengan berbagai macam bentuk. Permainan dilakukan dengan bimbingan dari pendamping yang ada di Rumah Singgah Autis Kota Palangka Raya. Masing - masing anak diberikan satu buah squishy selama 15 - 60 menit secara bertahap selama 3 bulan. Aktivitas yang dilakukan adalah membiarkan anak untuk memegang dan meremas squishy hingga dapat bermain squisy bersama - sama teman atau pendamping.

Data didapat dari pengisian kuesioner ceklist yang dilakukan oleh pendamping berdasarkan pengamatan pendamping terhadap kemampuan komunikasi anak. Pengisian kuesioner dilakukan setiap I bulan untuk melihat perkembangan komunikasi ank.

Data tersebut akan dianalisis secara univariat dan beberapa variabel akan dilakukan uji Analisis Bivariat. Langkah selanjutnya variabel - variabel tersebut akan dilakukan uji hubungan rencananya dengan uji non Parametrik (bila data tidak berdistribusi normal) yaitu Uji Wilcoxon. Pengujian dilakukan pada taraf signifikasi $\alpha$ $=0,05$. Bila hipotesis nilai Hasil kurang dari Alpha maka ada hubungan signifikan variabel tersebut. ${ }^{6}$

\section{HASIL DAN PEMBAHASAN}

\section{A. Analisis Univariat}

I. Karakteristik responden berdasarkan kelompok usia

Kelompok Umur Responden

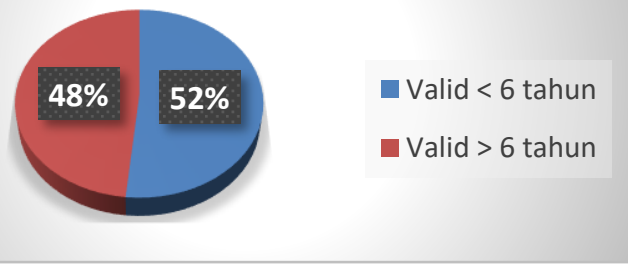

\section{Gambar I Karakteristik responden} berdasarkan usia

Berdasarkan gambar I pengelompokan usia responden kurang dari 6 tahun hampar sama banyaknya dengan responden unur $>6$ tahun yaitu sebanyak 16 responden (52\%). 1

2. Karakteristik responden berdasarkan jenis kelamin

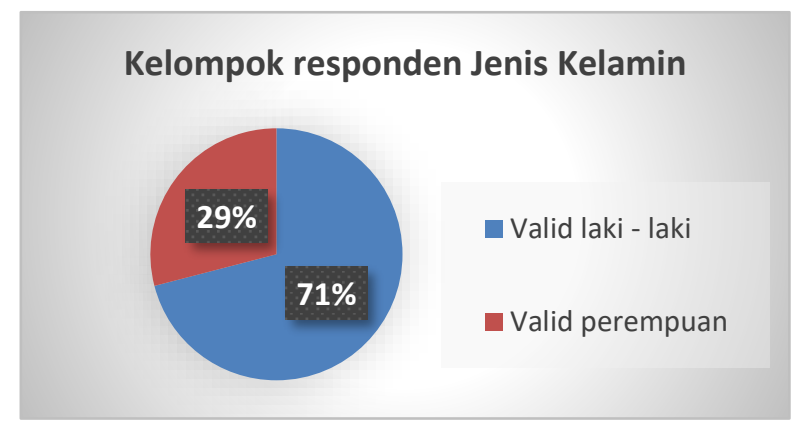

\section{Gambar 2 Karakteristik responden} berdasarkan Jenis Kelamin.

Berdasarkan Gambar 2, jumlah responden dengan jenis kelamin laki-laki lebih banyak dibandingkan dengan responden perempuan yaitu sebanyak 22 responden (7I\%).

3. Karakeristik responden berdasarkan jenis ganggungan Autisme

\section{Jenis Gangguan Autisme}

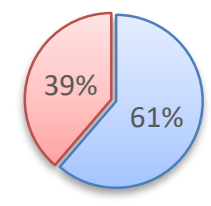

$\square$ Valid Interpersonal $\square$ Valid perkembangan bahasa

\section{Gambar 3 Karakteristik respondenberdasarkan Jenis Gangguan Autisme}

Berdasarkan Gambar 3, jumlah responden dengan jenis gangguan interpersonal lebih banyak dibandingkan dengan ganggungan perkembangan Bahasa. 
4. Karakteristik Responden berdasarkan kemampuan dalam permainan Squisy yang diukur secara periodic.

\section{KEMAMPUAN PLAY SQUISY}

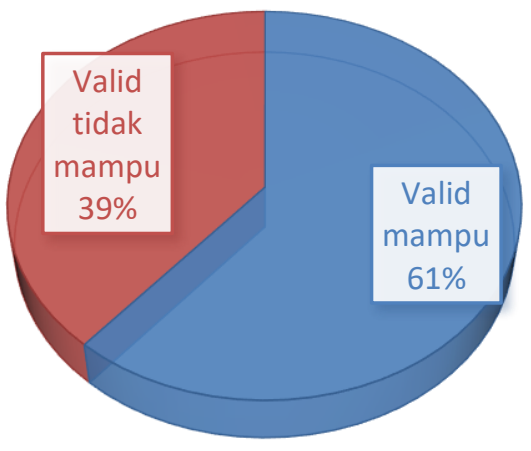

Gambar 4 Karakteristik responden berdasarkan Kemampuan dalam permainan Squishy

Berdasarkan Gambar 4, ada sebanyak 19 (61\%) responden yang mampu melakukan permainan Squisy cukup lama dibandingkan dengan reponden yang tidak mampu (39\%).

5. Karakteristik responden berdasarkan kemampuan sebelum dan sesudah pemberian permainan Squisy secara periodic.

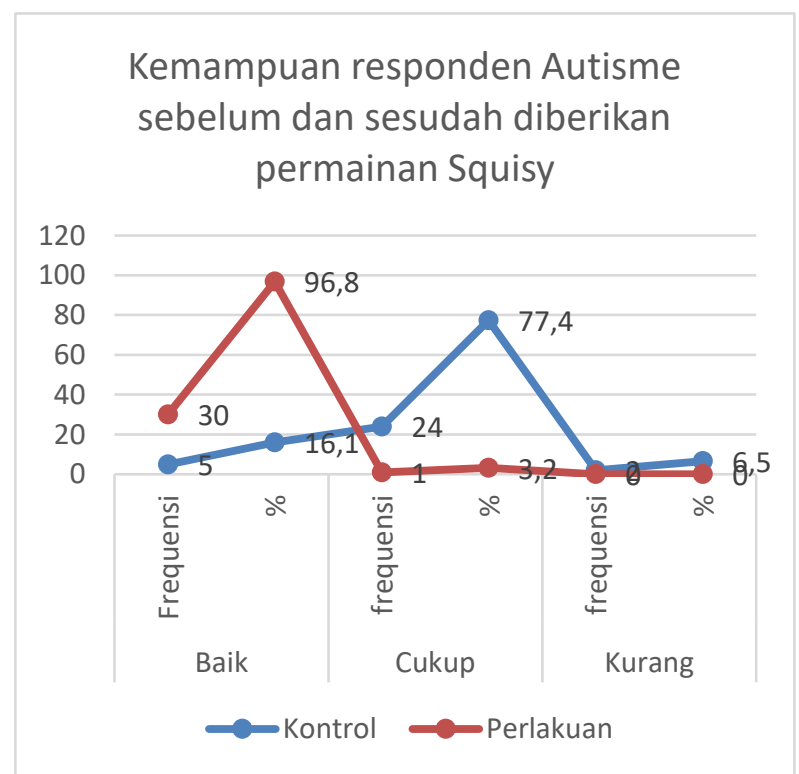

Gambar 5 Karakteristik responden berdasarkan kemampuan sebelum dan sesudah dilakukan intervensi dengan permainan Squisy
Berdasarkan Gambar 5 menunjukan hasil Penelitian menggambarkan responden dengan kemampuan mereka untuk melakukan permainan Squisy selama kurang lebih I jam secara periodik. Dari perlakukan tersebut terlihat ada peningkatan kemampuan responden yang sebelumnya (Kontrol) yang baik melakukan hanya 5 (16.1\%) saja setelah mendapatkan perlakuan meningkat menjadi 30 (96.8\%) responden. Begitu juga sebelum diberikan perlakuan masih ada responden yang kurang mampu (6.5\%) dalam melakukan permainan Squisy ini, setelah mendapat perlakuan secara periodic tidak ada lagi responden yang tidak mampu melakukan permainan Squisy ini.

\section{B. Analisis Bivariat}

I. Pengaruh Pemberian Squisy terhadap kemampuan komunikasi anak dengan Autisme.

Tabel I Hasil Uji diketahui pengaruh Responden sebelum diberikan perlakuan (Kontrol) dan setelah diberikan perlakuan permainan Squisy terkait komunikasi anak dengan Autisme.

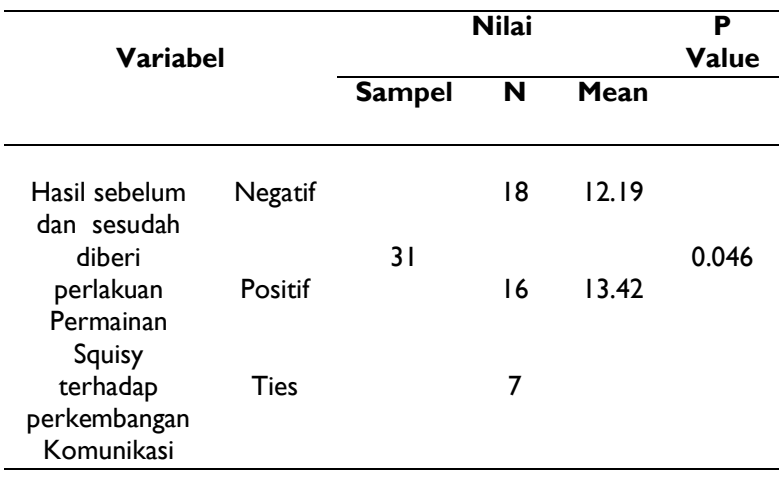

Dari hasil uji penelitian pada tabel tersebut diketahui $P$ Value < Alpha $(0.046<0.05)$. Dapat diartikan bahwa ada perbedaan yang bermakna pemberian permainan Squisy kepada anak Autisme terhadap perkembangan komunikasi mereka.

Dari hasil penelitian pengaruh pemberian permainan Squisy terhadap kemampuan dalam komunikasi sebelum dan sesudah diberikan perlakuan permainan Squisy memiliki pengaruh yang bermakna bagi anak Austisme. Pengaruh tersebut memberikan perubahan yang 
awalnya anak-anak Autisme tersebut tidak/belum terjadi perubahan yang berarti, namun setelah diberikan permainan Squisy secara periodic terjadi perubahan perkembangan kemampuan dalam komunikasi, Selain diperkuat dari hasil uji yang memiliki pengaruh yang bermakna tersebut, hal ini diperkuat juga dari gambaran perjalanan hasil peningkatan kemampuan yang terlihat pada tabel 5 yaitu hasil Penelitian kemampuan mereka untuk melakukan permainan Squisy selama kurang lebih I jam secara periodik. Hasil tersebut memperkuat ada peningkatan kemampuan anak-anak dengan Autisme yang sebelumnya (Kontrol) anak Autisme yang mampu melakukan dengan baik hanya sebesar $16.1 \%$ saja namun setelah mendapatkan perlakuan meningkat menjadi $96.8 \%$.

2. Hasil penelitian responden hubungan permainan Squisy terhadap kemajuan komunikasi anak Autisme

Tabel 2 Hasil Uji diketahui hubungan permainan Squisy terhadap kemajuan komunikasi anak dengan Autisme.

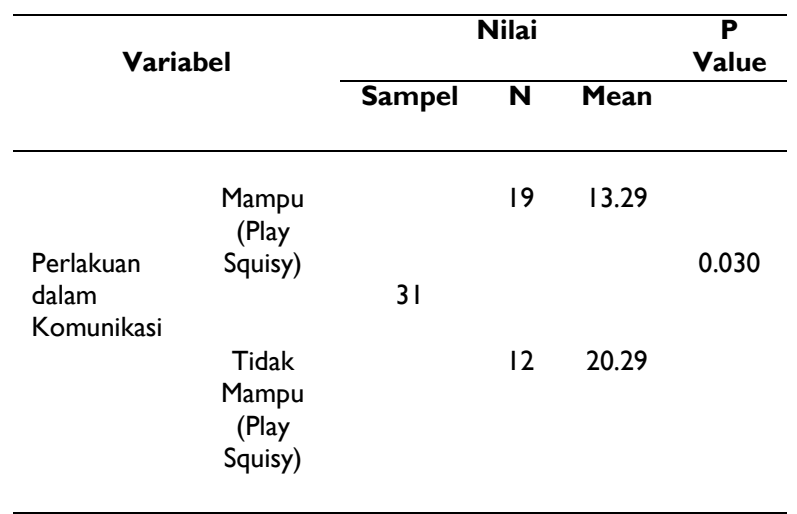

Dari hasil uji penelitian pada tabel tersebut diketahui $P$ Value < Alpha $(0.030<0.05)$. Dapat diartikan bahwa ada hubungan yang bermakna pemberian permainan Squisy kepada anak Autisme terhadap perkembangan komunikasi mereka.

Pada penelitian ini selain ada perbedaan sebelum dan sesudah pemberian Squisy terhadap komunikasi, diketahui juga dari anak-anak Autisme yang mampu melakukan dan yang kurang/tidak mampu melakukan permainan tersebut terhadap perkembangan mereka dalam melakukan komunikasi dua arah. Hal ini diperkuat melalui hasil penelitian ini yang dimana beberapa anak Autisme mampu melakukan permainan squisy dengan baik sesuai yang diharapkan. Walaupun masih ada beberapa anak yang kurang mampu melakukan akan tetapi pengaruh permainan Squisy memberikan dampak yang cukup baik bagi anak dengan keterbutuhan khsus tersebut.

3. Hasil penelitian responden hubungan permainan Squisy dalam perkembangan interaksi sosial anak Autisme.

Tabel 4.8 Hasil Uji diketahui hubungan permainan Squisy berpengaruh terhadap perkembangan Interaksi Sosial anak dengan Autisme.

\begin{tabular}{|c|c|c|c|c|c|}
\hline \multirow{2}{*}{\multicolumn{2}{|c|}{ Variabel }} & \multicolumn{3}{|c|}{ Nilai } & \multirow[t]{2}{*}{$\begin{array}{c}P \\
\text { Value }\end{array}$} \\
\hline & & Sampel & $\mathbf{N}$ & Mean & \\
\hline \multirow[t]{2}{*}{$\begin{array}{l}\text { Perlakuan } \\
\text { dalam } \\
\text { Interaksi } \\
\text { Sosial }\end{array}$} & $\begin{array}{l}\text { Mampu } \\
\text { (Play } \\
\text { Squisy) }\end{array}$ & 31 & 19 & 11.76 & 0.001 \\
\hline & $\begin{array}{c}\text { Tidak } \\
\text { Mampu } \\
\text { (Play } \\
\text { Squisy }\end{array}$ & & 12 & 22.71 & \\
\hline
\end{tabular}

Dari hasil uji penelitian pada tabel tersebut diketahui $P$ Value < Alpha $(0.001<0.05)$. Dapat diartikan bahwa ada hubungan yang bermakna pemberian permainan Squisy kepada anak Autisme terhadap perkembangan interaksi sosial mereka.

Pada penelitian ini juga memberikan jawaban bahwa pemainan Squisy mampu memberikan perkembangan perubahan bukan hanya kemampuan komunikasi akan tetapi kemampuan dalam hal interaksi social. Hasil uji pada penelitian ini menunjukan bahwa ada hubungan yang bermakna setelah pemberian permainan Squisy baik bagi anak Autisme yang mampu dan tidak mampu melalukan permainan ini memberikan pengaruh baik terhadap perkembangan anak autisme dalam interaksi social. Hasil penelitian ini sejalan dengan pernyataan Lola Binkerd, dalam tulisannya di Stress Cube, mainan seperti squishy dan Action figures dapat membuat jari-jari 
anak tetap sibuk. Mainan yang menimbulkan suara atau pola yang menenangkan dapat membuat anak-anak fokus bermain dan mengalihkan perhatian mereka dari kepanikan. Melalui proses pemberian permainan Squisy ini mampu memberikan perubahan untuk dapat berinteraksi dan terhindar dari kepanikan. ${ }^{8}$

\section{KESIMPULAN}

Pemberian permainan Squisy memberikan dampak yang positif bagi perkembangan komunikasi yang baik bagi penderita anak Autis. Hal ini karena didasari dari hasil penelitian ini sebelum dan sesudah diberikan perlakuan permainan Squisy memiliki hubungan yang bermakna

\section{UCAPAN TERIMA KASIH}

Ucapan terima kasih kepada seluruh sivitas akademika yang telah membantu dalam proses Penelitian. Enumerator Penelitian yang meluangkan waktu dalam pengumpulan data. Instansi Rumah sakit sebagai tempat penelitian yang telah memberikan kesempatan.

\section{REFERENSI}

I. Priherdityo, E. I5April 2017, Indonesia Masih 'Gelap" Tentang Autisme. Retrieved fromCNNIndonesia:http://www.cnnindonesia.co m/gaya-hidup/20 I60407 |60237255 I 22409/ indonesia-masih-gelap-tentang-autisme/

2. Yosfan Azwandi. (2005). Mengenal dan Membantu Penyandang Autisme. Direktorat Pembinaan Tenaga Kependidikan dan Ketenagaan Perguruan Tinggi, Jakarta.

3. MS. Sumantri, 2005. Model Pengembangan Keterampilan Motorik Anak Usia Dini. Jakarta: Depdiknas,Dirjen Dikti.

4. Abdul hadis. (2006). Pendidikan Anak Berkebutuhaan Khusus Autistik. Bandung: Alfabeta

5. Paul, R. \& Sutherland, D., (2005). Enhancing early language in children with autism spectrum disorders. In Volkmar, F. R.,Paul, R., Klin, A., \& Cohen, D. (Eds.), Handbook of Autism andPervasive
Developmental Disorder (pp. 946-976). New Jersey:John Wiley \& Sons, Inc

6. Deddy Mulyana. (20I2). Ilmu komunikasi Suatu Pengantar. Bandung: PT. Remaja Rosdakarya.

7. Arief M. Pengantar Metodologi Penelitian untuk IImu Kesehatan. Surakarta: CSGF (The Community of Self Help Group Forum); 2014.

8. Puput Fajar Widyaningrum, Peningkatan Kemampuan Motorik Halus Dengan Metode finger Paintingpada Anak Autis Kelas lii Sdlb Di Slb Negeri I Sleman, 2013 